\title{
MAURICE MERLEAU-PONTY AND ALEX GARLAND: Human Consciousness in Ex Machina
}

FISHER PRESSMAN

A lex Garland's science-fiction film Ex Machina is the story of Ava, an artificially intelligent robot, as she undergoes a Turing test, an examination aimed at determining whether an artificially intelligent entity is conscious. Garland forces the audience to ask what it means to be conscious, and whether a machine can have consciousness.

Maurice Merleau-Ponty stands as one of the most recognized existentialist philosophers of the twentieth century, who used phenomenological analysis to "demonstrate how the world is an experience which we live before it becomes an object which we know." He emphasizes the uniqueness of the body, as "more than an instrument or a means; it is our expression in the world, the visible form of our intentions." ${ }^{2}$ In this way, Merleau-Ponty's philosophy provides a powerful tool for reading the film Ex Machina, particularly with respect to Garland's choice to use an incarnate robot, and the robot Ava's use of art as pre-linguistic expression.

\section{PHENOMENOLOGY AND EXISTENTIALISM}

Philosopher Richard Kearney suggests that "phenomenology and existentialism attempt to relocate the origins of meaning in our lived experience prior to the

1 Richard Kearney, Modern Movements in European Philosophy (Manchester, NY: Manchester University Press, 1995), p. 1.

2 Maurice Merleau-Ponty, "Prospectus" in Robert Solomon, Existentialism (New York, NY: Oxford University Press, 2005), p. 275. 
impersonal 'objectivism' on a narrow scientific attitude." 3 The renewed focus on lived experience, with an emphasis on being over objective truth, was a response to the increased focus on empirical and scientific methods being incorporated into philosophy and other disciplines in the late nineteenth and early twentieth centuries. ${ }^{4}$ This shift towards positivism confined truth as one-dimensional, and, as a result, was met with a new approach towards understanding relation to the world ${ }^{5}$.

Phenomenology, according to Robert Solomon, "is the explicit conceptual manifestation of an existential attitude - a spirit of the 'present age."' 6 He suggests that existentialism is an expression between harsh reason and the celebration of the individual. He concludes: "Existentialism is this self-discovery. Its presupposition is always the Cartesian 'I am' (not 'I think')." It is not something to be defined, he argues, but an expression, a mood, a discovery of the self, with an essential understanding that personal, lived experience is our entry point into the absurdity of life, which begins with 'I am.'

\section{MERLEAU-PONTY AND EXISTENTIALISM}

Maurice Merleau-Ponty is widely considered a leading figure in phenomenological philosophy. Merleau-Ponty writes in Phenomenology of Perception that phenomenology is "the study of essences [...] such as the essence of perception or the essence of consciousness." His project in this text is to examine what constitutes human experience and being in the world. He asserts that a study of human existence can be examined only through a study of phenomena as it relates to the essence of human facticity. ${ }^{10}$

For Merleau-Ponty, lived experience is necessary for being; the experience of being is not some abstraction of 'I think,' but 'I am.' He suggests that the world is a place in which we live and with which we communicate, but not something that any person can possess. The facticity of the world established the "Weltlichkeit der Welt [worldliness of the world]," which allows for the embodied experience of being. ${ }^{11}$ It is the facticity of living - of being in the world - that enables the "recognition that the body is not an object amongst objects, to be measured in purely scientific or geometric terms, but a mysterious and expressive mode of belonging to the world of our perceptions, gestures, sexuality and speech."12 The necessary component for experiencing the world, for Merleau-Ponty, is the body, which allows for a means of

3 Kearney, Modern Movements in European Philosophy, p. 1.

4 Ibid., p. 2.

5 Ibid., p. 2.

6 Robert Solomon, Existentialism (New York, NY: Oxford University Press, 2005), p. xi.

7 Ibid., p. xii.

8 Ibid., p. xx.

9 Maurice Merleau-Ponty, Phenomenology of Perception (New York, NY: Routledge, 2012), p. xxi.

10 Ibid., p. xxi.

11 Ibid., p. xxxi.

12 Kearney, "Maurice Merleau-Ponty" in Modern Movements of European Philosophy, p. 73. 
opening the cogito to the world around it. This body is what senses, experiences, and lives, and from which our consciousness derives its relation to the world. MerleauPonty discusses the importance of the body for lived experience as our point of intentionality in the world in his work Prospectus (A Report to the College de France). He writes: ${ }^{13}$

The perceiving mind is an incarnated mind. I have tried, first of all, to reestablish the roots of the mind in its body, and in its world, going against doctrines which treat perception as a simple result of the action of external things on our body as well as against those which insist on the autonomy of consciousness. These philosophies commonly forget - in favor of a pure exteriority or of a pure interiority - the intersection of the mind in corporeality, the ambiguous relation which we entertain with our body and, correlatively, with perceived things. ${ }^{14}$

Human existence is not some abstraction, coming from the mind alone as other philosophers suggest, but is the lived, embodied experience and our relation to the world. Solomon comments that "our bodies are not simply objects in the world (to which each of us has privileged but yet contingent access). The body is our Being-inthe-world, the perspective from which we perceive, judge, value." ${ }^{15}$

It is clear from this analysis that it is the body that gives us access to the world and provides us with a platform through which we can experience. Kearney writes: "the 'phenomenon' of our embodied consciousness is precisely that 'in-between' realm l'entredeux - which pre-exists the division into subject and object." 16 To be in the world is to have an experiencing body-subject, which is the platform for thought, for feeling, and for outward expression towards others. Kearney concludes his analysis on the philosopher with a discussion of what being-in-the-world means for MerleauPonty: "We might sum up the adventures of Merleau-Ponty's phenomenological dialectic in terms of this multiple, reversible equation: I think (consciousness) - I perceive (nature) - I express (language) - I create (art) - I relate with others (history) - I exist in the flesh of the world (Being)." 17

\section{CRITIQUE OF LANGUAGE, THE BODY, AND THE ROLE OF ART}

A second major contribution of Merleau-Ponty is his critique of language, and his analysis of our signification in, and to, the world. Kearney writes, "To perceive the world is already to make sense of it, to transform it into signs by expressing an intentional project of meaning. Our carnal interrelationship with others is

13 Ibid., p. 73.

14 Merleau-Ponty, "Prospectus," p. 274.

15 Solomon, "Maurice Merleau-Ponty" in Existentialism, pp. 271-272.

16 Kearney, "Maurice Merleau-Ponty" in Modern Movements of European Philosophy, p. 75.

17 Ibid., p. 90. 
therefore indicative of an intentional 'signification." 18 Merleau-Ponty argues that to make meaning of the world is to use language as a "sort of being," as language's "opaqueness, its obstinate reference to itself, and its turning and folding back on itself are precisely what make it a mental power; for it in turn becomes something like a universe, and it is capable of lodging things themselves in this universe." ${ }^{19}$ In this way, it is language that gives rise to being through the interpretation of the body-subject. It is through the body-subject in the world that one can signify and interpret the signs from others. ${ }^{20}$ Further, it is the use of language that creates the facticity of being necessary for human consciousness. As Merleau-Ponty notes in the above passage, through language one can situate oneself in the universe, and signal to others through linguistic mediation.

An important aspect of language is the speech-act. Speech enables one to connect with another individual, or as Merleau-Ponty writes, "to express is to become aware of another and himself." ${ }^{11} \mathrm{He}$ concludes, "Speech ... is that moment when the significative intention ... proves itself capable ... of shaping me and others." ${ }^{22}$ Speech plays a crucial role in shaping culture and relating to others, and allows for an interrelationship with people in the world. ${ }^{23}$ It is essential in establishing the human's position in the universe, and it is what gives rise to the facticity of being. However, these signs are not limited to just language through speech. Movement, too, is the expression of the thoughts of the body-subject. Merleau-Ponty writes: "Language bears the meaning of thought as a footprint signifies the movement and effort of a body." ${ }^{24}$ Each individual has a unique style, conveyed through the movement, art, and speech of the body. He states that "style is the system of equivalencies that he makes for himself for the work which manifests the world he sees. It is the universal index of the 'coherent deformation' by which he concentrates the still scattered meaning of his perception and makes it exist expressly." ${ }^{25}$ The pre-linguistic signifying to others is this individual style, which is achieved through external expression. Merleau-Ponty gives the reader an important example of the style of the body-subject in the world in his book Signs. He writes:

A woman passing is not first and foremost a corporeal contour for me, a colored mannequin, or a spectacle; she is 'an individual, sentimental, sexual expression.' She is a certain manner of being flesh which is given entirely in her walk or even in the simple shock of her heel on the ground - as the tension of the bow is present in each fiber of wood - a very noticeable

18 Ibid., p. 79.

19 Merleau-Ponty, Signs (Northwestern University Press, 1964), p. 43.

20 Kearney, "Maurice Merleau-Ponty" in Modern Movements of European Philosophy, p. 79.

21 Merleau-Ponty, Signs, p. 90.

22 Ibid., p. 92

23 Ibid., p. 92.

24 Ibid., p. 44.

25 Ibid., p. 55. 
variation of the norm of walking, looking, touching, and speaking that I possess in my self-awareness because I am incarnate. ${ }^{26}$

This passage clearly details what Merleau-Ponty means by style. The "woman passing" is not some robotic façade; rather, she is made a being-in-the-world by her style, her "walking, looking, touching, and speaking," which constitute her unique set of expressions - set of gestures as pre-linguistic language - which give rise to her understood consciousness. ${ }^{27}$

Finally, Merleau-Ponty highlights the use of art (whether painting or poetry) as a means of expression in the world: a mix of the style of movement, and a reflection of the pre-linguistic expression that body-subjects necessarily employ. As Kearney notes: "Merleau-Ponty argues that artistic forms such as painting, music, and poetry provide a privileged access to the hidden workings of language. Behind the transparency of secondary expression, art reveals the indirect voices of primary expression." 28 It is through art that the artist can interpret "the world out of everything he lived" by constituting "his corporeal or vital situation in language." 29 Merleau-Ponty suggests that art can reveal our experience in the world, and can, as Kearney writes, open a "'universal realm of primary expressions ... a language common to all body subjects." ${ }^{30}$ Primary expression through pre-reflective art allows for translation across linguistic systems or cultural barriers, and allows for communication between people of varied backgrounds. ${ }^{31}$

\section{PHENOMENOLOGY IN EX MACHINA}

The film Ex Machina directly addresses the question of human existence, and the phenomenology of Maurice Merleau-Ponty offers an exceptional means of discussing the film and its presentation of artificial intelligence. The film is the story of Caleb, a young programmer, who is selected to perform a Turing Test on the AI Ava, created by Nathan. ${ }^{32}$ The film is loosely structured around a series of seven interviews (or tests) performed by Caleb over the course of a week, during which he tries to determine if Ava is self-conscious. Caleb becomes increasingly enamored by Nathan's creation, and ultimately helps Ava to escape from the facility. Director and writer Alex Garland uses the film as a medium to discuss what it means to be conscious; what it means for something to have sentience. He responds in an interview:

26 Ibid., p. 54.

27 Ibid., p. 54.

28 Kearney, "Maurice Merleau-Ponty" in Modern Movements of European Philosophy, p. 80.

29 Merleau-Ponty, Signs, p. 64.

30 Kearney, "Maurice Merleau-Ponty" in Modern Movements of European Philosophy, p. 81.

31 Ibid., p. 81.

32 A Turing Test is a test devised to determine if a computer has the ability to think. The test involves a human interacting with a computer, with the computer attempting to convince the human that it (the machine) is a human. A successful computer would be able to imitate a human so well as to convince the human examiner that it was sentient. If a computer can act and react like a human, then it should be considered able to think. In the context of Ex Machina, Nathan admits that Ava is clearly a machine, yet asks Caleb to continue with a Turing Test to assess weather the machine (Ava) can still pass, or be viewed as conscious, by a human. 
If you talk about the problems of strong artificial intelligence and let's say self-awareness - a self-aware machine - then you are immediately talking about human consciousness. That immediately brings you into the territory of how humans interact with each other, let alone how they interact with the machine. Really just how sentience encounters and understands sentience. How does one consciousness know or feel sure what is happening inside another consciousness? ${ }^{33}$

It is clear that Garland has an interest similar to Merleau-Ponty regarding what consciousness is and how we know if someone, let alone some machine, is sentient. Two features of Merleau-Ponty's phenomenology facilitate an interesting discussion of the problem of consciousness. Garland uses the choice of a physically bodied subject for the robot, Ava, and allows her to create drawn art as a means of presenting her existence in the world - both key concepts for Merleau-Ponty's existentialism. ${ }^{34}$

The first approach that Garland uses to discuss the consciousness of Ava is through her representation as a carnal body, which moves, talks, and feels. The body is a central part of Merleau-Ponty's understanding of consciousness because it is the mechanism through which one experiences the world. As noted above, consciousness is achieved only through "the intersection of the mind in corporeality, the ambiguous relation which we entertain with our body and, correlatively, with perceived things." 35 Ava's body has a special significance in the film because of the structure of the Turing Test used by Nathan and Caleb. Garland intentionally creates Ava with a machine-body that forces anyone interacting with her to know that she is a robot, yet still to believe that the robot is conscious. Nathan, Ava's creator, says in scene 22 that "the real test is to show you she is a robot. Then see if you still feel she has consciousness." ${ }^{36}$ In an interview, Garland comments on the decision to give Ava a body, saying "the first time she appears, there's no doubt about her machine status. Large parts of her body are transparent and you can see through them." ${ }^{37}$ He continues, "Hopefully that starts to sort of introduce the more humanlike aspects of her in a sort of physical representation ... a sense of life, but a sense of life which is other in some way." ${ }^{38}$ It is essential that Ava have a body because it is what gives her the sense of life, as well as a platform to interact with Caleb and Nathan; the body is also a prerequisite for consciousness according to Merleau-Ponty.

Later in the film, Caleb asks why it is necessary that Ava have a physical body. ${ }^{39} \mathrm{He}$ asks Nathan, "Why did you give her sexuality? An AI doesn't need a gender. She

33 O'Hehir, Andrew, "Dark Secrets of the Sex Robot: Alex Garland Talks A.I., Consciousness and Why 'the Gender Stuff of Ex Machina is Only One Part of the Movie's Big Idea” (Salon Magazine, 2015).

34 I will be using the pronouns she, her, and hers, herself when describing the robot Ava. I will also use pronouns like it and its to describe the robot. The pronouns used mirror the gendered pronouns used in the film, as well as non-gendered pronouns used in the discussion of specific traits for a robot or non-living being.

35 Merleau-Ponty, "Prospectus" in Existentialism, p. 274.

36 Garland, Ex Machina (2015), p. 26.

37 All Things Considered, "More Fear of Human Intelligence Than Artificial Intelligence in Ex Machina". (2014)

38 Ibid. [My italics]

39 Garland, Ex Machina, Scene 55. 
could have been a grey box." 40 Nathan responds to Caleb, "Actually, I'm not sure that's true. Can you think of an example of consciousness, at any level, human or animal, that exists without a sexual dimension? What imperative does a grey box have to interact with another grey box? Does consciousness exist without interaction?"41 The distinction is clearly made between Ava - a robot with senses - and a grey box the normal subject of a Turing Test. A physical body is necessary, as Merleau-Ponty suggests, to walk, look, touch, and speak. ${ }^{42}$ Another important aspect here is the sexuality of the robot; it is important for Garland to represent Ava as "an individual, sentimental, sexual expression," and not just as a box that interacts with speech alone. ${ }^{43}$ It is the mix of a "system of systems devoted to the inspection of the world and capable of leaping over distances, piercing the perceptual future, and outlining hollows and reliefs, distances and deviations" that gives life to Ava, and which enables her to be a body-subject in the world. ${ }^{44}$

The importance of her physical body is most powerfully displayed in the final scenes of the film, when the newly escaped Ava adopts a style by literally creating her final human body and, at the end of the film, when she moves through a crowd of people. These two scenes clearly show that human movement of gesture "embodied in the form of a 'style' which mediates between symbolizer and spectator." 45

The first of these instances takes place in the final ten minutes of the film, after Ava has killed her creator, Nathan. She walks into Nathan's room where other previous versions of AI robots are kept, and she begins to layer synthetic skin onto her robotic frame. It is also in this scene where she picks her final cut of hair (from a selection of wigs), and selects a dress to wear out in the world. The second notable instance is her entry into the world, as she leaves the house and enters the human world. In this scene, Ava is mixed in a crowd of other people and, as someone moves past Ava, she too disappears into the mass of other individuals. These two events can be read as the final attempts for Garland to present Ava as having created her own style, that "system of equivalencies that he makes for himself for the work which manifests the world he sees." ${ }^{46}$ Ava has made that her style, and her distinct expressions are her manifestation in the world. These final instances are, as Kearney writes, both prime examples of the creation of meaning as "both within and without, both subjective and objective, spiritual and material; it reveals that Being is not some mindless initself which threatens our free expression, but an intercorporeal life-world which gives us meanings and summons each body-subject to recreate these meanings for

\footnotetext{
40 Ibid., p. 55.

41 Ibid., pp. 55-56.

42 Merleau-Ponty, Signs, p. 54.

43 Ibid., p. 54.

44 Ibid., p. 67.

45 Richard Kearney, “The Dialectical Imagination (Merleau-Ponty)" in Poetics of Imagining (New York, NY:

Fordham University Press, 1998), p. 134.

46 Merleau-Ponty, Signs, p. 55.
} 
itself." ${ }^{47}$ For the viewer, it appears that Ava has become sentient during the film. Through her carnal embodiment and sexual gesturing, Ava has achieved the "walking, looking, touching, and speaking" which is present for incarnate self-awareness. ${ }^{48}$ Further, she has become the body-subject, embodying the "perceptions, gestures, sexuality and speech" which exists for beings-in-the-world, and has created her own distinct manifestations in the world by the end of the film through speech, style, and dress. ${ }^{49}$ These pre- and post-linguistic signifyings through speech and motion are the necessary components of being for Merleau-Ponty, and it is clear that Ava has achieved being through her speech and motion. The principles of phenomenology described by Merleau-Ponty offer an interesting and poignant analysis of Ex Machina through the prerequisite to be incarnate before conscious.

The second important reference point between Garland's film and Merleau-Ponty's phenomenology is the reliance on art as a means of communication, especially for Ava. There are several importance scenes in which Ava draws/creates art while she is confined in her quarters. The first example of her drawing takes place during the 'Session 2' interview between Caleb and Ava. ${ }^{50}$ She says to him, "I brought you a drawing." 51 The notes in the script describe this first drawing presented to Caleb as "totally abstract ... a mesh of tiny black marks, that swirl around the page like iron filings in magnetic field patterns." 52 As their conversation continues, it is evident that Ava is unsure what the drawing is, or why she made it, though she draws every day that she can. There are several other examples of Ava's art throughout the film. She presents to Caleb a drawing of her room (or containment area), and then later in the film, Ava draws a likeness of Caleb, presumably to show her affection for him. She is also shown several times (over security cameras) during the film to be drawing while nobody is interacting with her.

This recurring depiction of Ava creating art is important because it relates to Merleau-Ponty's notion of art as a means of pre-linguistic expression, and is used by Garland to again highlight the sentience Ava possesses. Merleau-Ponty suggests that accomplished artwork is that which has the ability to connect with the viewer in a meaningful way, and to invite the viewer into the world of the artist, leaving the previously "silent world of the painter" now "uttered and accessible." 53 Ava's drawings represent this type of art, which reaches out to Caleb and allows him to access her consciousness through pre-linguistic expressions. The role of art in the film is important to give another means of humanizing the machine, to prove that while she does have the exterior of a robot, she also has thought, and the means of expressing this thought with gesture, ultimately giving rise to her being-in-the-world.

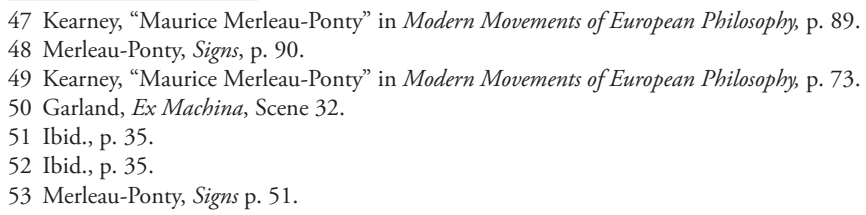


Finally, another important scene focuses on art, but does not directly involve Ava. The two men are in the midst of a conversation regarding Ava's supposed affections for Caleb when Nathan asks Caleb about a painting in the room. ${ }^{54}$ Nathan answers his own question to Caleb: "Jackson Pollock. The drip painter. He let his mind go blank, and his hand go where it wanted. Not deliberate, not random. Someplace in between. They called it automatic art." ${ }^{55} \mathrm{He}$ continues, "The challenge is not to act automatically. It's to find an action that is not automatic. From talking, to breathing, to painting." This is remarkably similar to Merleau-Ponty's discussion of the influential impressionist painter Henri Matisse, and is directly applicable to the discussion of human consciousness. He says of Matisse's painting style:

A camera once recoded the work of Matisse in slow motion... everything happened in the human world of perception and gesture; and the camera gives us a fascinating version of the events only by making us believe that the painter's hand operated in the physical world where an infinity of options is possible. And yet, Matisse's hand did hesitate. Consequently, there was a choice and the chosen line was chosen in such a way as to observe, scattered out over the painting, twenty conditions which were unformulated and even informulable for any one by Matisse. ${ }^{56}$

The Pollack painting in the film has the same meaning for Garland as does the Matisse painting for Merleau-Ponty. Matisse "did hesitate," before creating his masterful works of art, in order to create his works of art in a manner that only Matisse was able to perfect. ${ }^{57}$ In an almost identical manner, Nathan discusses the Pollack painting, saying that it is "not deliberate, not random," but someplace in between. ${ }^{58}$ The painting in the film stands as a representation for Ava, the robot, and her feelings towards Caleb as a being-in-the-world. She does not act precisely as some machine might, nor does she act with complete randomness; rather, Ava, like Matisse, acts with a calculated precision, sometimes hesitating, which gives rise to her consciousness and sexuality. Her body, like Matisse or Pollack's hands, is her "expression in the world, the visible form of [her] intentions." 99 Merleau-Ponty's philosophy provides a powerful explanation for the role of art in Ex Machina, both through the robot's creation of art and through discussions concerning art creation as a phenomenon of existence.

\section{CONCLUSION}

Merleau-Ponty's phenomenological analysis offers several powerful tools that the viewer can use to decipher and analyze Alex Garland's film Ex Machina. These philosophical tools help the viewer to understand Garland's use of an embodied,

54 Garland, Ex Machina, Scene 50A.

55 Ibid., p. 58.

56 Merleau-Ponty, Signs, pp. 45-6.

57 Ibid., p. 46.

58 Garland, Ex Machina, p. 59.

59 Merleau-Ponty, "Prospectus," p. 275. 
even sexual, robot who creates art in the context of human consciousness and being-in-the-world. And, on the flip side, Garland unintentionally employs some of Merleau-Ponty's most important philosophical contributions regarding both being and consciousness in his film to discuss whether artificial intelligence has reached sentience. His choices to create Ava as carnal and his focus on art are both clearly intended to create an AI that the audience believes is sentient. It is fascinating that while Merleau-Ponty's phenomenology explains AI through embodied experience, other notable philosophers have used his phenomenology to criticize the notion of non-human human consciousness. The writing of Hubert Dreyfus stands as perhaps the best example of this criticism. He comments: "Heidegger, Merleau-Ponty, and Michael Polanyi have devoted a deal of thought to" the question regarding the "essential difference between meat machine and metal machine, between being embodied and controlling movable manipulators." ${ }^{60}$ His conclusion, though, is the opposite of Alex Garland's. Dreyfus firmly believes that the concept of artificial intelligence "seems magical from the point of view of science"; he remarks, "there is no reason to suppose that a world organized in terms of the body should be accessed through any other means." But perhaps that is the power of film, of the aesthetic art form Garland uses. It seems that the failure of AI in the scientific fashion articulated by Dreyfus is a failure Merleau-Ponty might not recognize, for both Merleau-Ponty and Garland operate in the "domain of the phenomenal," in questions of existence, and not in objective truth or positivist logic. Merleau-Ponty insists that we must go beyond science to question the world for ourselves through lived experience, and Ex Machina presents to the viewer a fascinating experience of consciousness, of the interconnectivity of individuals, and of the deceit of human will.

\section{BIBLOGRAPHY}

All Things Considered. "More fear of human intelligence than artificial intelligence in 'ex machina'.” National Public Radio [database online]. 2014. http://www.npr. org/2015/04/14/399613904/more-fear-of-human-intelligence-than-artificialintelligence-in-ex-machina.

Dreyfus, Hubert L. "Artificial Intelligence." The Annals of the American Academy of Political and Social Science, vol. 412, 1974, pp. 21-33.

Ex Machina. Alex Garland, Universal Pictures International, FilmFour (Firm), DNA Films, Lions Gate Entertainment [Firm], 2015.

Kearney, Richard. The dialetical imagination (Merleau-Ponty). Poetics of Imagining: Modern to Post-modern. 2nd ed., New York: Fordham University Press. 1998

60 Hubert Dreyfus, Artificial Intelligence (Sage Publications, 1974), p. 31. 
- Modern Movements in European Philosophy. Manchester; New York: Manchester University Press. 1995

Merleau-Ponty, Maurice. Signs. Translated by Richard C. McCleary, eds. John Wild, James M. Edie, Herbert Spiegelberg, George A. Schrader, William Earle, Maurice Natanson, Paul Ricoeur and Aron Gurwitsch. United States of America: Northwestern University Press. 1964

Landes, Donald A.,. Phenomenology of Perception. Abingdon, Oxon; New York: Routledge. 2012

O’Hehir, Andrew. "Dark secrets of the sex robot: Alex garland talks A.I., consciousness and why "the gender stuff" of "Ex machina" is only one part of the movie’s big idea." Salon Magazine. 22 April 2015.

Solomon, Robert C., Existentialism. New York: Oxford University Press. 2005 